\title{
SUBJECTIVE PERCEPTION OF THE REALITIES OF MODERN PHYSICAL EDUCATION CLASSES AMONG PHYSICAL EDUCATION TEACHERS AND STUDENTS IN HIGHER GRADES
}

\author{
Edita Maciulevičienè1, Jolanta Gedvilienė ${ }^{2}$ \\ Lithuanian Sports University', Kaunas, Lithuania \\ Mykolas Romeris University², Vilnius, Lithuania
}

\begin{abstract}
Background. Intense changes in national education require new students' teaching technologies in physical education. There are a number of studies, published books or articles on the topics of modern physical education classes and they provide guidance for teachers, but we believe that there is a lack of modernity in the reality of physical education, still focusing on sports lessons avoiding non-traditional content of the lessons. Research aim was to reveal the subjective opinions of physical education teachers and students in higher grades about the realities of modern physical education classes.

Methods. The sample included physical education teachers $(n=33)$ and $10-11^{\text {th }}$ grade students $(n=324)$, who were selected applying the convenience sampling strategy from Kaunas city schools. The research employed a questionnaire by Pate, Corbin, and Pangrazi (1998), and some more questions of interest to the researchers were added. The survey was conducted in spring of 2012. The research participants were surveyed in their schools during the classes with the consent of physical education teachers and students and with the permission of school administration received in advance.

Results. Students more often pointed out the lack of attention to individual work and its implementation, just one-fifth of the students indicated that lessons met their needs and physical education teachers sometimes met modern requirements, showing sincerity, respect, etc. The survey showed that physical education classes were still largely dominated by sports and movement skills, and only sometimes by the non-traditional or healthy lifestyle. Teachers more often than students highlighted the progress and initiative criteria. The most common means of discipline for students in physical education were a whistle and loud shouting.

Conclusion. Physical Education teachers tend to subjectively better evaluate the contemporary realities of physical education classes compared to students. Teachers more often indicated that they applied independent work in their lessons, and thought that the lesson content met the needs of the students and led enough to unconventional physical activity and healthy lifestyle. Students more often pointed out that teachers never assessed them according to their progress in the development of their physical qualities and knowledge during lessons. In the opinions of teachers and students, physical fitness test results are still common evaluation criteria in the lessons.
\end{abstract}

Keywords: lesson, physical education, modern, teachers.

\section{INTRODUCTION}

I ntense changes in national education require new students' teaching technologies in physical education. Modern general Physical Education program increases students' self-confidence, nurtures the need for physical activity, reasoned disposition to look for, try and find a variety of physical education activities, encourages students to be physically active not only during PE lessons at 
school, free time, but after leaving school (Pradinio ir pagrindinio ugdymo bendrosios programos, 2008; Sandercock, Ogunleye, \& Voss, 2013).

Lithuanian teachers play a very important role in helping students to acquire new knowledge, which would become personal self; skills enabling them to meaningfully explore, learn; formation of value orientations; creative and meaningful way of thinking, etc. (Bagdonienè \& Blauzdys, 2005). Teachers of today and the future must also teach physical education to their students to remain physically active for the rest of their life (Himberg, Hutchinson, \& Roussell, 2003; Shephard \& Trudeau, 2000). Unfortunately, a lot of teachers of physical education conduct their classes using traditional rather than the modern methodology, apply usual tools which are boring to students. For these reasons, many secondary school students at the age of adolescence form a stereotype of passive learning, and the higher the grade, the students are more passive, their physical activity decreases, and the result is the deteriorating health of the country's students (Vilkas \& Raškauskienè, 2005). However, this problem has not been widely analysed, there is a lack of a more detailed research on it by comparing the newly submitted ideas and recommendations to the General Physical Education Programme and its real execution.

Himberg et al. (2003) offers to give students the choice of all possible sports activities. Students having limited choice of sports lose the need for exercise, they feel that they can choose only a few physical activities, and if none of them appeals to them, the only option left is to be physically inactive. Choices have to focus on the life and health promoting activities (Shephard \& Trudeau, 2000).

Knowledge is a cognitive tool of physical education and its important functions. Acquisition of knowledge is an important intelligence training method. Consequently, the traditional narrow physical education teachers' attitude to knowledge is unacceptable today. There are students who practice physical self-education, but not everyone has the necessary knowledge, clear goals and motives of sport. Therefore, knowledge promotes interest in not only the physical self-education in a narrow sense. It is a way of life planning, communication skills, and positive attitudes to learning, etc. (Blauzdys \& Vilkas, 2007). The aforementioned statements reveal the topicality of the analysed problem and enable the formulation of the study aim - to reveal the subjective opinions of physical education teachers and students in higher grades of the realities of modern physical education classes.

\section{METHODS}

Research group included 33 physical education teachers (21 women and 12 men) and 324 students from $10-11^{\text {th }}$ grades (168 girls and 156 boys) selected using a convenience sampling strategy from Kaunas city schools.

The research employed a questionnaire by Pate et al. (1998), and some more questions of interest to the researchers were added. The survey was conducted in spring of 2012. The questionnaire for teachers included 24 questions, for students -22 questions. The answers to them helped reveal the subjective opinions of the research participants about the realities of modern physical education classes.

The research participants were surveyed in their schools during the classes with the consent of physical education teachers and students and with the permission of school administration received in advance. The survey was based on the ethical and legal research principles. All participants were informed about the objectives of the study and the anonymity of the data. It was emphasized that participation in the study was not compulsory. Participants were asked to answer the questions honestly.

Survey data were processed using the program SPSS for Windows 14. Comparing the groups for statistical difference of data, the significance was tested using Student's $(t)$ and the chi-square $\left(\chi^{2}\right)$ criteria. Results were considered statistically significant if the error probability was $p \leq .05$ at $95 \%$ reliability.

\section{RESULTS}

According to the survey data, the students and teachers' opinions on the independent work in classes did not coincide $(p<.001)$. More than half (63.6\%.) of physical education teachers and $25.9 \%$ of students admitted that independent work was trained in lessons; however, $9.1 \%$ of teachers and $21.3 \%$ of students denied that. The study also found that students' and teachers' subjective opinions on the compliance of the content of the lessons with the needs of the students did not coincide as well $(p<.001)$. Physical Education teachers more often 
stated that they believed that the content of lessons met the needs of the students $(63.6 \%$ and $22.2 \%$ respectively), while $53.7 \%$ of students and $9.1 \%$ of teachers indicated that only sometimes the content of lessons met those needs. Students (24.1\%) and accordingly $27.3 \%$ of teachers indicated that physical education lesson content does not meet the needs of students.

Aiming at ascertaining whether the content of lessons really met the needs of the students, we asked teachers whether creating themed lesson plans they consulted with the students what sports activities they would like to do during PE lessons. It was found that $54.5 \%$ of physical education teachers consulted with students while developing annual thematic plans, while a third (36.1\%) of students indicated that teachers just sometimes wanted to consult about sports activities $(p<.05)$. Other students $(63.9 \%)$ and teachers (36.4\%) indicated that they never discussed about the desired sports activities $(p<.05)$.

Analysing the realities of contemporary physical education classes, it is important to figure out what is taken into account while assessing students' achievements as seen by the teachers and students. It was observed that in this regard the opinions differed (Table).

Physical education teachers (Table 1) more often than students that the assessment was based on sports technical performance, progress in the development of physical skills and activity during lessons (effort, activity, initiative) $(p<.05)$, but a quarter of students observed that teachers never valued their progress in the development of physical skills and activities in the lessons $(p<$ .05 ). However, results of physical fitness tests are still common assessment criteria both for students and teachers.
In addition, students were asked how often their physical education teacher met the modern requirements for teachers providing clear descriptions. It was noticed that half of the students surveyed $(50.9 \%)$ stated that physical education teachers sometimes took care of poorer health or disabled students and ingeniously integrated them into physical education classes and non-formal education. Sometimes physical education teachers were friendly, creative, respected their learners considering their desires $(40.7 \%)$, discussing sports, food supplements, nutrition, safe physical activity, sports clubs, and other topics relevant to the learners (49.1\%). Also teachers sometimes gave the opportunity to try sports and find favourite forms of physical activity, appropriate physical exercises and encouraged the motivation for daily physical activity (46.3\%). Fewer (41.9\%) students thought that teachers sometimes selected the content of the lessons taking into account students' gender, age, health, physical fitness, physical and spiritual attitudes. Sometimes physical education teachers of $41.7 \%$ of students explained tasks and significance and benefits of exercises, and teachers of other $41.7 \%$ of students explained for what learners would be assessed and what parts of the assessment would be. One third (39.8\%) of subjects indicated that for their teachers all students were equal, and students talented for sports as well as adolescent leaders were never distinguished. Meanwhile, half (50.9\%) of subjects teachers never visited the class parent meetings to discuss the situation of students' physical education, solutions and support of parents and never personally communicated with parents of children with poorer health or other problems. Also, $63.9 \%$ of teachers never conducted questionnaire surveys on students' attitudes towards PE lessons, and physical

\begin{tabular}{|c|c|c|c|c|c|c|}
\hline \multirow[b]{2}{*}{ Variants of responses } & Teachers & Students & Teachers & Students & Teachers & Students \\
\hline & \multicolumn{2}{|c|}{$\begin{array}{c}\text { Always } \\
\%(n)\end{array}$} & \multicolumn{2}{|c|}{$\begin{array}{c}\text { Sometimes } \\
\%(n)\end{array}$} & \multicolumn{2}{|c|}{$\begin{array}{l}\text { Never } \\
\%(n)\end{array}$} \\
\hline $\begin{array}{l}\text { Physical fitness test } \\
\text { results }\end{array}$ & $54.5(18)$ & $43.5(141)$ & $18.2(6)$ & $32.5(105) *$ & $27.3(9)$ & $24.1(78)$ \\
\hline $\begin{array}{l}\text { Technical performance } \\
\text { of a sport }\end{array}$ & $81.8(27)$ & $38.6(125)^{*}$ & $18.2(6)$ & $46.3(150) *$ & $0.0(0)$ & $19.7(64) *$ \\
\hline Knowledge & $27.3(9)$ & $7.4(24) *$ & $63.6(21)$ & $38.6(125) *$ & $9.1(3)$ & $54.6(177) *$ \\
\hline $\begin{array}{l}\text { Progress in the } \\
\text { development of physical } \\
\text { skills }\end{array}$ & $81.8(27)$ & $35.2(114)^{*}$ & $9.1(3)$ & $38.6(125) *$ & $0.0(0)$ & $25.3(82) *$ \\
\hline $\begin{array}{l}\text { Efforts, initiative, } \\
\text { activity }\end{array}$ & $72.7(24)$ & $\begin{array}{l}38.6(125) \\
*\end{array}$ & $27.3(9)$ & $37.0(120)$ & 00. (0) & $25.3(82) *$ \\
\hline Attendance of classes & $54.5(18)$ & $53.7(174)$ & $36.4(12)$ & $36.1(117)$ & $9.1(3)$ & $10.2(33)$ \\
\hline
\end{tabular}

Table 1. Distribution of assessment criteria for physical education teachers and students

Note. $*-p<.05$, compared to teachers' responses. 
Figure. Distribution of frequency data of physical education lesson content
Note. ${ }^{* *}-p<.01-$ compared to students' responses.

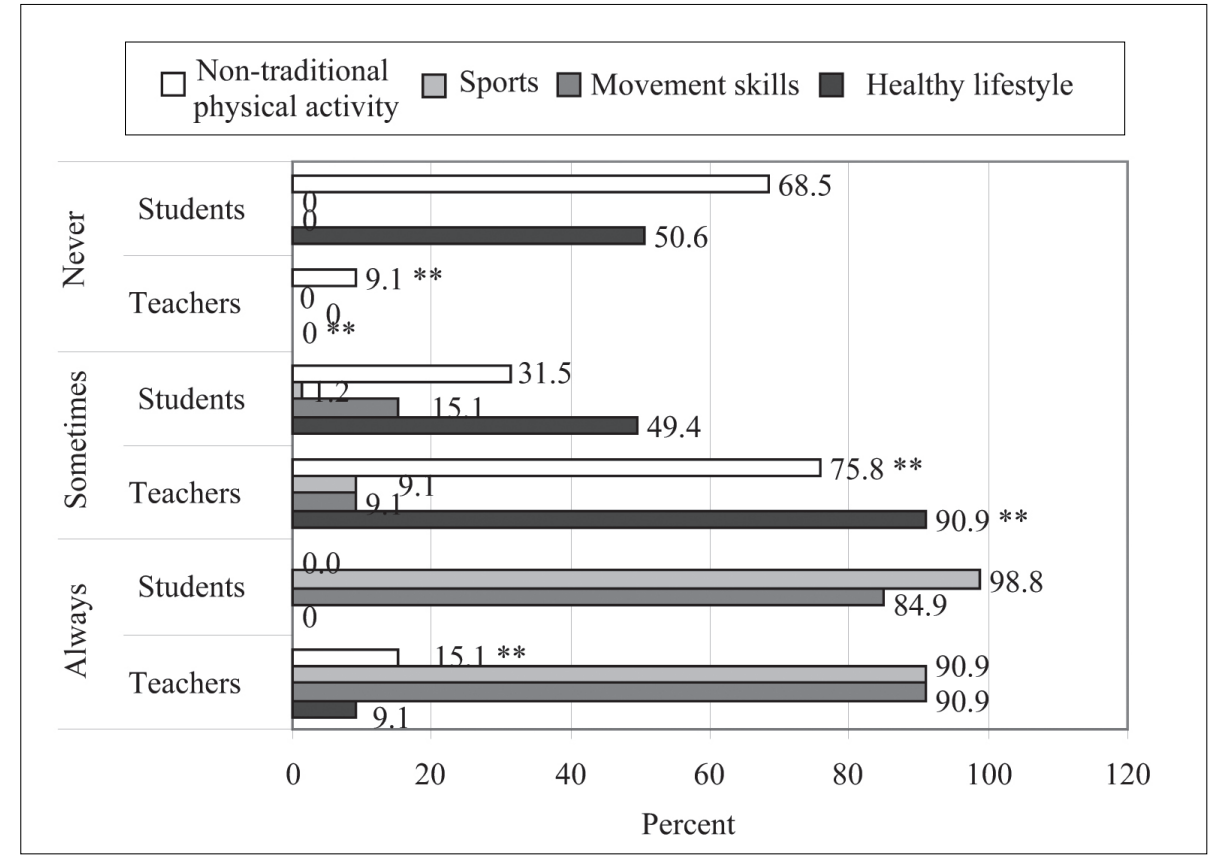

education teachers of $61.1 \%$ of students never improved their professional qualifications, looked for innovations, or communicated with Lithuania and / or foreign schools. Slightly fewer (45.4\%) teachers never started lessons with presenting the objectives and never discussed the outcomes. The listed data show that the studied physical education teachers are partly consistent with the requirements of modern teacher.

The findings revealed that physical education teachers often conducted lessons of movement skills and sports (Figure).

Teachers more often than students (Figure 1) indicated that they always or sometimes conducted healthy lifestyle and non-traditional physical activity classes $(p<.01)$, and about half of the students said that this never happened $(p<.01)$. The findings showed that in most cases lessons on sports and movement skills are carried out. Teacher and student opinions did not coincide on this option.

The survey data showed that most teachers preferred traditional disciplinary measures for students which are not recommended in modern classes. Both teachers and students reported that most often the buzzer was used in the classes $(90.9$ and $92.3 \%$ respectively), students often pointed out that teachers screamed loudly (respectively 39.4 and $55.5 \%, p<.01$ ), and teachers often stated that they clapped their hands (45.5 and $30.2 \%$ respectively, $p<.01)$.

\section{DISCUSSION}

According to the survey conducted, independent work and its implementation are given too little attention, although research, teaching experience show that students' independent work during physical education lessons is one of the most important ways to not only improve the quality of the lessons, but also to teach and reinforce the need to act independently in the classes: increase physical activity, improve health. It is important to convince the students that taking care of their physical development and maturity is not only a personal matter, but also a civic duty. Independent work is the kind of activity that contributes to the achievement of knowledge, abilities and skills, and develops ownership of the process of learning, as well as helps to form the appropriate psychological attitude to cognitive activity. Finishing secondary school the students must be able to do physical exercises independently and consciously develop his/her body (Dumčienė, Malinauskas, Sipavičienè, \& Klizas, 2007; Kviklienè, Vilkas, \& Kontorovičienè, 2005).

Modern physical education not only promotes the autonomy of the students, but also encourages teachers to be innovative. Physical education program must be based on standards, but it also must take into account the needs of the students, focus on the development of skills, and emphasize students' understanding of how to become 
physically active throughout their lives (Himberg et al., 2003; Shephard \& Trudeau, 2000). This is confirmed by the Lithuanian General Education Programme (Pradinio ir pagrindinio ugdymo bendrosios programos, 2008), which states that the school programme must meet the various needs of a specific class of students. In our study, only onefifth of the students reported that lessons met their needs, which reveals the poor response to model of the modern lessons. This is also confirmed by other research results, where we can see that in most cases physical education teachers did not discuss matters with the students what sports activities they would like to have in the classes and do not take into account their needs, which according to Himberg et al. (2003) reduces the need for students to play sports and be physically active at school and after school, which diminishes the main goal of the General Physical Education Programme - to develop students' physical activity for life. Strategic education documents set the goal to adapt the curriculum so that every pupil could mature according to their needs (Bendrojo lavinimo ugdymo turinio formavimo, igyvendinimo, vertinimo ir atnaujinimo strategija, 2006).

Vilkas and Raškauskienè (2005) argue that the choice to attend physical education classes usually is influenced by physical education teacher, and the least it is influenced by the students' parents and friends. Therefore, the teacher's desire to be modern and not to be afraid of challenges is of great importance. A significant influence to physical education classes as well as the emotional atmosphere of learning and educational outcomes is achieved by the nature of teachers' relationships with students. Teacher morale, good will directly influence students' mood, work capacity, and approach to lesson content. Only a sincere and friendly relationship can create exhilaration that promotes efficiency and increases satisfaction with a teacher (Grigaliūnienè, Vèlavičienè, Šulga, \& Keblys, 2007). Our study also shows that physical education teachers sometimes met modern requirements. Therefore Poteliūnienè, Blauzdys, \& Juškeliene (2012) believe that in the development of modern physical education teacher, it is important to emphasize teachers' pedagogical and psychological maturity, which would lead the students' positive attitudes to become physically active throughout their lives.

During lessons it is advisable to use the methods of education which teach students to observe, try to choose what is most useful to them, which will help to improve and learn to explain, and and justify their choice for senior students. Unusual methods of physical education and methodological techniques should be applied (Rekomendacijos dèl kūno kultūros déstymo gerinimo, 2005). The research showed that PE classes still largely dominated by sports and movement skills, and only sometimes they were non-traditional or about healthy lifestyle. Teachers conducted unconventional physical education lessons are very important and students are pleased (Lykesas, Koutsouba, \& Tyrovola, 2009). According to Gudynas, Kazragyte, Motiejūnienè, and Žadeikaitè (2010), when a lesson is not only learning the subject, but also the learning objectives concerning general competences, such lesson is efficient. Non-traditional classroom includes not just students learning the subject. Students are taught to plan, responsibly implement their plans, work in groups, reflect on the learning process and results and set further goals. Students find out their favourite ways of learning, and sufficient capacity for improvement as well as their learning options. So, the lesson not only deepens the subject knowledge and skills, but also develops general competences.

While assessing students, the General Physical Education Programme (Pradinio ir pagrindinio ugdymo bendrosios programos, 2008) proposes to consider the students' physical abilities, to each student's individual characteristics and each student's progress. Our study revealed that teachers paid attention to assessing attendance, but more often they took into account their individual efforts and improvements, which according to Morgan Sproule, and Kingston (2005), gives all students the opportunity to experience success. Physical education teachers sometimes have difficulty in assessing students' physical abilities; they lack a uniform system of assessment and evaluation methods as well as specific examples. However, the traditional evaluation which involves the comparison of students' physical education results does not meet the personal expectations of students. Therefore, individual progress evaluation, promotion and monitoring observations encourage students' desire to improve in physical education classes (Gudynas et al., 2010).

Modern physical education is a successful lesson, and its success is in the hands of the teacher (Butrimienè \& Damijonaitiene, 2013). So physical education teacher has the greatest impact on good 
emotional environment. In the lessons teachers need to give up the dictate, autocratic command and the student's personality suppression. Teaching should be based on positive learner characteristics, viewing a learner optimistically, believing in them. When the teacher in the lesson emphasizes the positive things and relies on them, mostly schoolchildren justify their confidence and improve the emotional environment in the lesson (Kvikliene et al., 2005; Galkienè, 2011). Our findings suggest that physical education teachers are more likely to command and often take the easiest decision in class control - using acoustic signals. Meanwhile, Kardelienė Kardelis, \& Bagdonas (2007) have found that teacher speaking is important for students. Most students enjoy when the teacher speaks figuratively, eloquently and correctly. National School Assessment Agency's annual report states that the lowest valued lesson aspects were learners' achievements assessment, student support and lesson planning, and in 2011, the teacher and student relationship remains the best evaluated lesson component (Bendrojo ugdymo mokyklu veiklos kokybe, 2012). The continuous development and use of modern methods enable physical education to become an integral part of other subjects, thus covering a harmonious physical and spiritual development of the students, which accompanies them to adulthood (Mededovic, Pljakic, Mededovic, Hožic, \& Muric, 2013; Trudeau \& Shephard, 2000).

\section{CONCLUSIONS}

Physical Education teachers tend to subjectively better evaluate the contemporary realities of physical education classes compared to students. Teachers more often indicated that they applied independent work in their lessons, and thought that the lesson content met the needs of the students and led enough to unconventional physical activity and healthy lifestyle. Students more often pointed out that teachers never assessed them according to their progress in the development of their physical qualities and knowledge during lessons. In the opinions of teachers and students, physical fitness test results are still common evaluation criteria in the lessons.

\section{REFERENCES}

Bagdonienè, L., \& Blauzdys, V. (2005). Prasmingos kūno kultūros pamokos ir jų itaka V klasės mokiniu fizinèms ypatybèms. Sporto mokslas, 3(41), 59-60.

Bendrojo lavinimo ugdymo turinio formavimo, igyvendinimo, vertinimo ir atnaujinimo strategija, 2006-2012. (2006). Retrieved from http://www.sac. smm.lt/images/UT\%20strategija\%202006-2012.pdf.

Bendrojo ugdymo mokyklu veiklos kokybe. Nacionalines mokyklu vertinimo agentūros metinis pranešimas. (2012). Retrieved from http://www.sac.smm.lt/images/ file/e biblioteka/MOKYKLU\%20vertinimo\%20 agenturos $\% 20$ metinis\%20pranesimas.pdf

Blauzdys, V., \& Vilkas, A. (2007). Kūno kultūros žinių poveikis gimnazijos mokinių fiziniam parengtumui. Ugdymas. Kūno kultūra. Sportas, 1(64) 10-15.

Butrimienè, R., \& Damijonaitienè, J. (2013). Mokymąsi skatinanti aplinka - raktas i pamokos sèkmę. Kauno miesto mokytoju konferencijos, skirtos švietimo reformos pradininkès habil. dr. Meilès Lukšienès 100-osioms gimimo metinèms, straipsniu ir pranešimu rinkinys, Kauno pedagogu kvalifikacijos centras (pp. 34-38). Retrieved from http://www.kpkc.lt/failai/dokumentai/ edukacines_patirties_bankas/gerosios_patirties_ leidiniai/2013/2013.pdf

Dumčienè, A., Malinauskas, R., Sipavičienè, S., \& Klizas. Š. (2007). Moksleivių sveikatinimo per kūno kultūros pamokas aspektai. Sveikatos mokslai, 3(50), 939-941.
Galkienè, A. (2011). Šiuolaikinio mokytojo vaizdinys: mokinių požiūris. Pedagogika, 101, 82-90.

Grigaliūnienè, V., Vèlavičienè, D., Šulga, J., \& Keblys, N. (2007). Aukštesniujų klasių moksleivių ir mokytojų santykių vertinimas ir jų itaka moksleivių psichinei sveikatai. Sveikatos mokslai, 3(50), 947-986.

Gudynas, P., Kazragytè, V., Motiejūnienè, E., \& Žadeikaite, L. (2010). Mokiniu pasiekimu ir pažangos vertinimo tobulinimo dorinio, meninio ir kūno kultūros ugdymo procese rekomendacijos. Vilnius: Švietimo aprūpinimo centras.

Himberg, C., Hutchinson, G. E., \& Roussell, J. M. (2003). Teaching secondary physical education. Preparing adolescents to be active for live. United States: Human Kinetics.

Kardelienė, L., Kardelis, K., \& Bagdonas, A. (2007). Būsimujų kūno kultūros mokytojų nuostatos dèl pedagoginès komunikacijos kaita. Ugdymas. Kūno kultūra. Sportas, 2(65), 23-29.

Kviklienè, R., Vilkas, A., \& Kontorovičienè, R. (2005). Ivairių edukacinių veiksnių itaka VII-VIII klasių mergaičiu nuomonei apie kūno kultūros pamokas. Sporto mokslas, 4(42), 64-68.

Lykesas, G., Koutsouba, M., \& Tyrovola, V. (2009). Creativity as an approach and teaching method of greek traditional dance in secondary education. Studies in Physical Culture and Tourism, 16(2), 207-214. 
Mededovic, A., Pljakic, B., Mededovic, E., Hožic, E., \& Muric, B. (2013). Physical Education improvement in the process of modern organization of work. Activities in Physical Education and Sport Federation of the Sports Pedagogues of the Republic of Macedonia, 3(1), 129-131.

Morgan, K., Sproule, J., \& Kingston, K. (2005). Effects of different teaching styles on the teacher behaviours that influence motivational climate and pupils' motivation in physical education. European Physical Education Review, 11(3), 1-27.

Pate, R., Corbin, C., \& Pangrazi, B. (1998). Physical activity for young people. President's Council on Physical Fitness and Sports Research Digest, 3(3), 1-6.

Poteliūnienè, S., Blauzdys, V., \& Juškelienè, V. (2012). Lietuvos kūno kultūros mokytojų pasirengimas taikyti naujas mokinių fizinio ugdymo idejjas. Pedagogika 105, 94-100.
Pradinio ir pagrindinio ugdymo bendrosios programos. (2008). Retrieved from http://www.pedagogika.lt

Rekomendacijos dèl kūno kultūros dèstymo gerinimo. (2005). Retrieved from http://www.upc.smm.lt/puslapis/ delkunok.doc

Sandercock, G. R. H., Ogunleye, A., \& Voss, C. (2013). Screen time and physical activity in youth: Thief of time or lifestyle choice. Journal of Physical Activity and Health, 9(7), 977-984.

Shephard, R. J., \& Trudeau, F. (2000). The Legacy of Physical Education: Influences on Adult Lifestyle. Pediatric Exercise Science, 12, 34-50.

Vilkas, A., \& Raškauskienè, J. (2005). 5-12 klasių mergaičiu požiūrio i kūno kultūrą formavimasis ir kaita. Sporto mokslas, 3(41), 66-67. 